\title{
Expertise and Ideology in Statistical Evaluation of Circumcision for Protection against HIV Infection
}

\author{
Brian J. Morris ${ }^{*}$, Gia Barboza², Richard G. Wamai ${ }^{3}$, John N. Krieger ${ }^{4,5}$ \\ ${ }^{1}$ School of Medical Sciences and Bosch Institute, University of Sydney, Sydney, Australia \\ ${ }^{2}$ Department of Cultures, Societies and Global Studies, School of Criminology and Criminal Justice, Northeastern University, \\ Boston, MA, USA \\ ${ }^{3}$ Department of African-American Studies, Northeastern University, Boston, MA, USA \\ ${ }^{4}$ School of Medicine, University of Washington, Seattle, WA, USA \\ ${ }^{5}$ Section of Urology, VA Puget Sound Health Care System, Seattle, WA, USA \\ Email: •brian.morris@sydney.edu.au
}

How to cite this paper: Morris, B.J., Barboza, G., Wamai, R.G. and Krieger, J.N. (2017) Expertise and Ideology in Statistical Evaluation of Circumcision for Protection against HIV Infection. World Journal of AIDS, 7, 179-203

https://doi.org/10.4236/wja.2017.73015

Received: July 12, 2017

Accepted: August 8, 2017

Published: August 11, 2017

Copyright (c) 2017 by authors and Scientific Research Publishing Inc. This work is licensed under the Creative Commons Attribution International License (CC BY 4.0).

http://creativecommons.org/licenses/by/4.0/

c) (i) Open Access

\begin{abstract}
Aim: To critically evaluate data and arguments by Van Howe defending his stance opposing male circumcision (MC), in particular his meta-regression analyses evaluating the ability of MC to reduce HIV infection risk in heterosexual populations within and outside Africa. Methods: We performed metaregression analysis of log odds of HIV infection between uncircumcised and circumcised men using a single covariate (MC prevalence) in the meta-regression model involving the metareg package in STATA 13 for 103 populations worldwide and for populations within Africa. The meta-regression of log odds and MC prevalence was fitted to a line, as were empirical Bayes estimates resulting from post-estimation. Results: Our critical evaluation of Van Howe's arguments attempting to undermine the scientific evidence in support of the benefits of MC in protection of men against HIV during heterosexual intercourse, as well as other infections and conditions, together with his use of statistics to support his beliefs, revealed serious flaws, obfuscation and missing data. We therefore performed our own meta-regression analysis using a trivariate model. Doing so revealed that for MC prevalences of 50\%, 75\% and $100 \%$ for general populations within Africa, odds ratios for HIV risk in uncircumcised vs. circumcised men were $1.35,1.58$ and 1.85 , respectively. Our meta-regression analysis of data for all countries yielded similar findings. For a general population outside Africa with $100 \%$ MC prevalence, OR was 1.5. Van Howe failed to acknowledge that since MC prevalence in US whites (91\%) and blacks (76\%) exceeds $75 \%$ his results support MC having a protective effect in those population groups. Conclusions: The protective effect of MC against
\end{abstract}


HIV infection during heterosexual intercourse applies to populations both within and outside Africa. The debate engineered by MC opponents, and led by Van Howe, now appears to have run its course. The scientific evidence has prevailed.

\section{Keywords}

Male Circumcision, Human Immunodeficiency Virus, HIV, Prevalence, Prevention, Meta-Regression, Global Health

\section{Introduction}

Despite strong evidence that male circumcision (MC) reduces the risk to men of human immunodeficiency virus (HIV) infection during heterosexual intercourse with an infected female partner, there are those who remain in denial or who insist that the findings are not relevant outside epidemic settings such as exist in Africa. While the claims by most MC opponents have been refuted convincingly, the statistical analyses used by one MC opponent, Robert Storms Van Howe, have presented more of a challenge to researchers. It is, nevertheless, important to science and public health to critically respond to all publications that appear to perpetrate false or misleading information. Here we address an extensive (19-page) defense by Van Howe [1] of our criticisms [2] of a meta-regression article he published comparing the prevalence of HIV and MC in 109 populations worldwide that led him to question the value of this procedure, particularly outside Africa [3]. In the present article we will show how, by statistical means and misrepresentation of published data, Van Howe has attempted to perpetuate his seemingly personal agenda that is opposed to MC, particularly of minors. We will, moreover, present results of our own meta-regression analyses spanning the full-range of MC prevalence $(0 \%-100 \%)$ to show that $\mathrm{MC}$ is effective at the population level for HIV reduction both within and outside Africa.

\section{MC Denialism}

Van Howe takes umbrage at published critiques by numerous researchers concerning his articles and analyses [2] [4]-[15], as well as the published critiques of articles by other MC opponents [16]-[59] misrepresenting and distorting the strong scientific evidence documenting various benefits of $\mathrm{MC}$ for prevention of infections and other adverse medical conditions in males. This regrettable approach by $\mathrm{MC}$ opponents jeopardizes public health efforts and puts global health and lives at risk.

The criticisms of Van Howe's work have been based on the consensus view of a substantial body of scientific literature. As a notable example, in table 1, item 10 of his defense article, Van Howe denies that heterosexual transmission is the main driver of HIV infection in Africa [1]. In item 11 of his table 1 (and referred to in his Note 9) Van Howe, by omitting the word "treatment", misconstrues a modelling study [60] that actually found, "The prevention benefits of HIV 
treatment were reaped primarily through high ART (anti-retroviral therapy) coverage", so misleading the reader. That study found high medical MC coverage combined with high ART coverage provided approximately the same reduction in HIV incidence as treatment as prevention (TaSP), but for US $\$ 5$ billion less over the period 2009-2020. The authors of that study stated, "The most cost- effective HIV prevention strategy is to expand medical MC coverage and then scale up ART" [60].

Much of Van Howe's argument attempts to bolster his reputation as an expert in statistics and the MC field. A PubMed search revealed 73 publications by Van Howe. All but 5 concerned MC, suggesting that the topic is one that he is passionate about. Most are letters to the Editor. Several include his wife, Michelle Storms. Other publications include several other MC opponents. But those devoted to meta-analysis and, more recently, meta-regression, are single-author publications by Van Howe alone.

His publication record might explain why Van Howe was invited by the US Centers for Disease Control and Prevention (CDC) to represent the "cause" of MC opponents at the CDC's meeting of stakeholders in 2007 to discuss national policy on MC as a public health strategy to reduce risk of HIV and other sexually transmitted infections (STIs), as well as various additional adverse foreskin-related medical conditions in the US [61]. Having Van Howe present his views would have helped those present at the meeting to come to a better understanding of the "evidence" used by MC opponents. In appreciation of his contributions in opposing MC, Van Howe was named as, "Intactivist of the Month" by the anticircumcision group "Intact America” (http://www.intactamerica.org/rvh). He also regularly speaks at intactivist conferences. The stated goal of "intactivism" is to end non-consensual circumcision, an ideology that, while appealing to some, is not consistent with the goals of preventive medicine of using evidence-based interventions such as MC and childhood vaccination for disease reduction.

\section{The "Specialized Expertise" of Van Howe}

We acknowledge the statistical expertise Van Howe has gained since his early attempts at meta-analysis. His first meta-analysis, on MC and HIV infection, [62] was criticized [4] because he used simple data pooling [63], leading to a Simpson's Paradox [64]. This work has been used in a textbook on meta-analyses [65] and in a review of methods and techniques in meta-analyses [66] to illustrate how data pooling can lead to incorrect results. His subsequent meta-analysis of MC and HPV infection [67] led to a critique by epidemiologists at the Catalan Institute in Barcelona entitled, "A Biased, Inaccurate and Misleading Meta-analysis" [7]. Given this history, we understand why Van Howe has gone to great lengths to convince others of his current knowledge of statistical methodology and terminology. We are concerned, however, at whether he has used his more recently acquired statistical knowledge objectively and whether he has presented his results impartially. 
Van Howe's use of meta-regression is justified when studies show a high level of heterogeneity. Curiously, Van Howe failed, however, to provide heterogeneity statistics for his meta-regression analyses. If he was trying to address heterogeneity by employing meta-regression, then it should have been obvious to a self-proclaimed statistical expert such as Van Howe of the need to present statistical results showing that heterogeneity had actually been reduced. Van Howe should also appreciate the need to justify adding complexity to an analysis by solving an underlying problem, not simply his own dissatisfaction with the results apparent from individual studies. A problem with meta-regression is that the number of possible meta-regression analyses of a set of data is usually enormous. One can make arbitrary choices of variables to include in the model, enabling an individual to generate results to the individual's liking.

Van Howe tries to demonstrate his superior statistical knowledge by criticizing a critique by Waskett and Morris [9] of his article with, "Sorrell [sic!] and colleagues" on fine-touch sensitivity of penile sites of uncircumcised and circumcised men [68]. But his criticisms seem off target. First, that study did not contain, "a single hypothesis that had been developed using pilot data", as stated in Van Howe's Note 1 [1]. Waskett and Morris rightly pointed out that Bonferroni correction should have been applied to the $P$ values arising from the multiple comparisons carried out by Sorrells et al. to test different sites on the penis for fine-touch sensitivity. Contrary to Van Howe's assertion, Waskett and Morris appreciated that, "someone with primary source expertise would know that Bonferroni adjustments are not used with marginal mixed models", and they did not suggest that the mixed model data required Bonferroni correction. The Letter by Young [69] cited by Van Howe misrepresented the critique by Waskett and Morris [9] and failed to understand appropriate use of the Bonferroni correction. The reader should examine the Waskett and Morris critique [9] in its entirety in order to appreciate the large number of errors and distortions in Sorrells et al. An obvious analysis that was not presented in Sorrells et al. was a comparison of fine-touch sensitivity for the same sites present on the penis of both circumcised and uncircumcised men. Therefore, in their critique, Waskett and Morris performed that analysis using those data from Sorrells et al. and found no statistical difference, even before Bonferroni correction for the multiple comparisons [9]. A subsequent study across all sensation types (touch, warmth and pain) by Canadian researchers, Bossio et al. [70] concluded that, "the foreskin is not the most sensitive part of the penis". Although the foreskin was sensitive to fine-touch, in referring to Sorrells et al. [68], Bossio et al. stated that their study, "challenges past research suggesting that the foreskin is the most sensitive part of the adult penis" [70].

Van Howe appears to think that raw data rather than data adjusted for potential confounding factors should be used for meta-analyses. We disagree, as do others. For example, Peters and Mengerson state, "If adjusted estimates cannot be obtained, the reasons for this should be investigated and sensitivity analyses could be used to assess the impact of this on the meta-analysis" [71]. 
We agree with Van Howe that all published critiques of his meta-regression analysis and his other articles should be read before deciding whether the results and claims in his publications have merit.

In the section entitled, "An effective critique requires specialised expertise" [1], Van Howe enunciates the sequential steps needed for the statistical analysis we criticized. The second author of our critique, Dr. Gia Barbosa, has the specialized statistical expertise Van Howe enunciates. What should be of concern is whether, in the hands of an expert with an agenda, statistical analyses might have been used to generate a result consistent with a predetermined outcome.

\section{What Makes an Expert?}

Van Howe correctly describes the difference between an individual with some knowledge of a topic and one with specialist knowledge, subcategorized according to whether that person has interactional or contributory expertise. As far as the critiques that have been directed at the work of MC opponents are concerned, the critics fall into the latter two categories. Several are professors of epidemiology and public health, well versed in statistical analyses used for analyzing their own data from research studies and have a track record of relevant publications in high quality journals, including publications on MC. Others are junior faculty with similar skills. The critics have been mostly scientists and physicians, but also lawyers and ethicists. Most hold professorial titles at major universities. Van Howe devotes particular attention to his nemesis, Brian Morris, a Professor Emeritus in medical sciences. In Table 1 we list systematic reviews, meta-analyses and risk-benefit analyses [18] [37] [52] [72]-[80] demonstrating the contributory expertise of the first author of the present article, Brian Morris, in publications, most of which have been co-authored with other experts in MC.

Van Howe nevertheless attempts to discredit his critics by questioning their expertise. Yet he has no qualms in uncritically citing the publications of MC opponents who lack specialist knowledge: for example, George Hill, a retired airline pilot and sugar farmer; Frederick Hodges, a jazz pianist; Dan Bollinger, an industrial designer; Robert Darby, an historian; Hugh Young, a retired broadcaster and publisher of dictionaries on Pacific Islander languages; Gregory Boyle, a psychologist; David Gisselquist, an economist and anthropologist; Brian Earp, an ethicist; Marilyn Milos, a fired nurse; Peter Adler, a lawyer; Steven Svoboda, a lawyer; Paul Mason, a lawyer; Ryan McAllister, a physicist; and the late Paul Fleiss, a convicted felon [81] [82], whose advocacy of alternative medicine, including denial of HIV as the cause of AIDS, insistence on breastfeeding despite a mother being unable to do so, and raw milk promotion, have had tragic outcomes [83]. Van Howe has, moreover, published with Adler [84], Bollinger [85], Darby [86], Fleiss [87] (three years after his felony conviction), Hodges [87] [88] [89] [90], Mason [35], Milos [68] [91] and Svoboda [84] [89] [90] [92] [93] [94]. Critiques undermining the claims by these individuals are referenced next to 
Table 1. Evidence of the contributory expertise of Morris to the male circumcision field.

\begin{tabular}{|c|c|c|}
\hline Topic & Publication type & Reference to publication \\
\hline $\begin{array}{l}\text { Risk vs. benefit: }>100: 1 \\
\text { Uncirc'd affected: } 1 \text { in } 3\end{array}$ & Risk-benefit analysis & Morris et al. (2006) [18] \\
\hline $\begin{array}{l}\text { Risk vs. benefit: }>100: 1 \\
\text { Uncirc'd affected: } 1 \text { in } 3\end{array}$ & Risk-benefit analysis & Morris (2007) [72] \\
\hline $\begin{array}{l}\text { Risk vs. benefit: }>100: 1 \\
\text { Uncirc'd affected: } 1 \text { in } 2\end{array}$ & Risk-benefit analysis & Morris et al. (2012) [73] \\
\hline $\begin{array}{l}\text { Risk vs. benefit: }>100: 1 \\
\text { Uncirc'd affected: } 1 \text { in } 2\end{array}$ & Risk-benefit analysis & Morris et al. (2014) [96] \\
\hline $\begin{array}{l}\text { Risk vs. benefit: }>100: 1 \\
\text { Uncirc'd affected: } 1 \text { in } 1.5\end{array}$ & Risk-benefit analysis & Morris et al. (2016) [52] \\
\hline $\begin{array}{l}\text { Risk vs. benefit: } ~ 200: 1 \\
\text { Uncirc'd affected: } 1 \text { in } 1.3\end{array}$ & Risk-benefit analysis & Morris et al. (2017) [74] \\
\hline $\begin{array}{l}\text { MC and lower oncogenic HPV } \\
\text { OR } 0.52(95 \% \text { CI } 0.33-0.82)\end{array}$ & Meta-analysis & Morris et al. (2011) [75] \\
\hline $\begin{array}{l}\text { Phimosis and penile cancer risk } \\
\text { OR } 12.1 \text { (95\% CI } 5.57-26.2)\end{array}$ & Meta-analysis & Morris et al. (2011) [75] \\
\hline $\begin{array}{l}\text { Balanitis and penile cancer risk } \\
\text { OR } 3.82(95 \% \text { CI } 1.61-9.06)\end{array}$ & Meta-analysis & Morris et al. (2011) [75] \\
\hline $\begin{array}{l}\text { Smegma and penile cancer risk } \\
\text { OR } 3.04 \text { (95\% CI } 1.29-7.16)\end{array}$ & Meta-analysis & Morris et al. (2011) [75] \\
\hline $\begin{array}{l}\mathrm{MC} \text { and reduction in penile } \\
\text { inflammatory skin conditions } \\
\text { OR } 0.32(95 \% \text { CI } 0.20-0.52)\end{array}$ & Meta-analysis & $\begin{array}{c}\text { Morris et al. (2012) [76] } \\
\text { Morris \& Krieger (2017) [98] }\end{array}$ \\
\hline $\begin{array}{c}\text { MC and meatal stenosis risk } \\
\text { Risk } 0.66 \%(95 \% \text { CI } 0.43 \text { - 0.91) }\end{array}$ & Meta-analysis & Morris \& Krieger (2017) [99] \\
\hline $\begin{array}{l}\text { MC and lower lifetime UTI risk } \\
\text { OR } 0.27 \text { (95\% CI } 0.085 \text { - 0.87) }\end{array}$ & $\begin{array}{l}\text { Systematic review and } \\
\text { meta-analysis }\end{array}$ & Morris \& Wiswell (2013) [77] \\
\hline $\begin{array}{l}\text { MC and sexual function, } \\
\text { sensitivity and sensation }\end{array}$ & Systematic review & Morris \& Krieger (2013) [37] \\
\hline $\begin{array}{l}\text { Country-specific and global } \\
\text { Prevalence of MC }\end{array}$ & Systematic review & Morris et al. (2016) [79] [80] \\
\hline MC, benefits and risks & Systematic review & Morris et al. (2017) [74] \\
\hline $\begin{array}{c}\text { MC and penile inflammatory skin } \\
\text { conditions }\end{array}$ & Systematic review & Morris \& Krieger (2017) [78] \\
\hline $\begin{array}{l}\text { World first patent for use of PCR } \\
\text { for viral (HPV) testing }\end{array}$ & $\begin{array}{l}\text { Patents: US, Australia, } \\
\text { Europe, Japan }\end{array}$ & $\begin{array}{c}\text { Morris \& Nightingale (1987) } \\
{[100]}\end{array}$ \\
\hline
\end{tabular}

each as follows: Adler [53] [57], Bollinger [22] [33], Boyle [29] [34] [37] [47], Darby [33] [51] [58], Earp [44] [55], Hill [34], Hodges [11], Gisselquist [25] [95], Mason [33], McAllister [20], Milos [9], and Svoboda [14] [57].

Contrary to Van Howe's assertion regarding a review published by Morris and co-workers in Mayo Clinic Proceedings [96], those workers did not, "claim credit for performing a meta-analysis" by Tian et al. [97]. That meta-analysis was clearly referenced in their review article. It is, moreover, misleading of Van Howe to assert that the large systematic review by Morris and Krieger [37] in Journal of Sexual Medicine that found sexual function, sensitivity and satisfac- 
tion did not differ between circumcised and uncircumcised men, "merely repeated the results of a meta-analysis performed by someone else" [97], because not only did Morris \& Krieger cite Tian et al., the study by Tian and co-workers only examined sexual function. Furthermore, Van Howe's implication that, by citing their "own 'review' of the literature", Morris et al. [37] introduced bias is unsustainable, given that not only the meta-analysis by Tian et al., but also a recent meta-analysis by Yang et al. [101] and systematic review from Denmark [102], together with a large probability survey in the UK [103], arrived at the same conclusion as Morris \& Krieger that MC has no adverse effect on sexual function. The meta-analysis by Yang et al. found, moreover, that MC improved intravaginal ejaculatory latency time by $28 \%$ and that pain during intercourse was $64 \%$ less frequent in men who were circumcised [101].

Van Howe acknowledged that the lead author of the recent critique, Morris, published a meta-analysis with Thomas Wiswell [77], a pediatrician who published the first large epidemiological studies [104] [105] and a meta-analysis in 1978 [105] showing that MC protected against urinary tract infections (UTI) in infancy, therefore demonstrating, "contributory expertise". But Van Howe misrepresented the 2013 meta-analysis by Morris \& Wiswell. He failed to point out that contrary to the meta-analysis by Singh-Grewal et al. [106] he cites in stating, "It was estimated that the number of infant circumcisions needed to prevent one [UTI] was 111", the meta-analysis by Morris \& Wiswell [77] presented findings for UTI risk contributed by the foreskin in an uncircumcised male over the entire lifetime (1 in 4). It is therefore hardly surprising that, "this number dropped to 4" for lifetime risk of UTI. Hardly, "a discrepancy that raises serious questions as to whether the analysis was performed correctly". In fact, this exemplifies the "legerdemain" Van Howe's critics accuse him of (as listed in his table 2, item 4) [1]. Indeed, he appears unable to resist the temptation of misconstruing data to undermine the validity of findings that support conclusions not to his liking. Curiously, he avoided any discussion of the odds ratio (OR) or risk ratio (RR), either of which are actually what a meta-analysis generates. Instead he mentioned number needed to treat (NNT) - a figure derived from the results. Contrary to his assertion that the meta-analysis by Singh-Grewal et al. [106] was, "by authors who no one considers to be partisan in this debate", the senior author of that study (Jonathan Craig) is likely an MC opponent. The study by Singh-Grewal et al. was criticized by a former Chair of the American Academy of Pediatrics Task Force on Circumcision, the late Edgar Schoen [6], for flawed, misleading and one-sided arguments. Schoen pointed out that, "studies of older children and adults [were] inappropriately included in the analysis". Schoen also pointed out that the fact that, "the prevalence of UTI in boys decreases with increasing age may explain why the odds ratio in boys is not as favorable as earlier studies". Being more recent (by 8 years), the meta-analysis by Morris and Wiswell [77] included more studies, determined level of protection conferred by MC at different ages, not just in infancy, estimated lifetime risk reduction conferred by MC, and was published in the world's top urology journal based on impact 
factor, Journal of Urology.

Van Howe presented an itemized list of things that "interactional experts" should know. Most of this misrepresents our criticisms of his publication [3], as the reader might appreciate by examining our critique [2]. Although we can provide a counter-point to each item he lists, we have confined our discussion to several of his more egregious comments.

In item 2 of his list, we agree with Van Howe that, "between-study heterogeneity from differences in study design can arise equally from randomized clinical trials as observational studies" [107]. The scientific data show that MC reduces heterosexual transmission of HIV from infected women to men by at least $60 \%$. Three randomized controlled trials (RCTs) in sub-Saharan Africa [108] [109] [110] are remarkable for their consistency in the level of protection observed [111] [112]. Risk ratio in each RCT was, respectively, 0.41 (95\% CI 0.24 - 0.69), 0.41 (95\% CI $0.24-0.69)$ and 0.43 (95\% CI 0.25 - 0.75) [112]. Interestingly, risk ratio for each RCT was similar to adjusted risk ratio found in a meta-analysis of observational studies, namely 0.42 (95\% CI 0.34 - 0.54) [113]. A Cochrane review [111] confirmed the validity of the RCT findings. The most recent metaanalysis of RCTs and observational studies found the protective effect of MC against heterosexual acquisition of HIV by men to be 0.70 (95\% CI $0.62-0.76$ ) [114].

In relation to Van Howe's item 5, we agree that meta-regression analysis applies to population risk, as stated in the reference we cited [115], so we reject his claim that we were not aware of this.

In his item 8, Van Howe stated that, "the purpose and advantage of multivariate analysis [is] seeing how each variable is impacted by the other, potentially confounding, variable". Unfortunately, this statement appears to contradict the statement he makes near the end of the third paragraph of his Introduction referring to a response [116] he published in which he, "details the dangers of using adjusted odds ratios in meta-analyses and explains why using raw data is preferred" [1]. This is an extraordinary and idiosyncratic claim. Most experienced statisticians agree that, if available, using adjusted data is essential to avoid the introduction of confounding influences.

In his item 9, Van Howe persists with his assertion that the small absolute risk reduction seen in the large RCTs in sub-Saharan Africa negates the validity of the results [1]. An interactional expert would understand RCT methodology, specifically that RCTs involve an external advisory committee whose job it is to halt a trial once there is evidence of the effectiveness of the intervention, so that the intervention can be offered to the control group [117]. The point Van Howe makes has been addressed previously by interactional and contributory experts [34]. Our critique stated, "He seems not to understand the way RCTs are conducted". Nor did Van Howe mention that the "absolute risk reduction" claim was published by MC opponents, Boyle \& Hill [118], who in turn stated they took it from an unpublished manuscript by Van Howe. Van Howe should be aware that an absolute risk reduction of $1.8 \%$ was calculated by the Cochrane 
committee in their systematic review and meta-analysis of the three trials [111] cited above. Boyle and Hill's article was severely criticized [34]. In particular, Boyle and Hill failed to point out that the significant absolute adjusted risk reduction of $1.3 \%$ (actually $1.8 \%$ ) was for the 2 -year point of the RCTs. Follow-up studies have shown continuation, even enhancement, of the protective effect of MC against HIV infection with time [119] [120] [121]. One might therefore expect a $1.3 \%$ (or $1.8 \%$ ) reduction after 2 years to increase to $13 \%$ (or $18 \%$ ) by 20 years. In a population of one million sexually active men this risk reduction would mean 130,000 (or 180,000) HIV infections averted over 20 years. Modelling has shown that circumcising 20 million men in 14 sub-Saharan African countries during 2009-2025 would avert 4 million new HIV infections over these 15 years [60]. But Van Howe either chooses to ignore or seems unable to address our explanation.

\section{Meta-Regression Analysis}

In his item 11, Van Howe appeared reticent to present the full complement of results arising from the trivariate analyses in his meta-regression [1]. Specifically, in table 3 of his article he presented ORs of HIV risk between uncircumcised and circumcised men for a general population within Africa with 5\%, 15\% and $25 \%$ MC prevalence, but not ORs for HIV risk when MC prevalence is 50\%, 75\% and $100 \%$. His univariate and bivariate models did show results for $50 \%, 75 \%$ and $100 \% \mathrm{MC}$ prevalence. Thus, his failure to present the missing results for $50 \%, 75 \%$ and $100 \%$ MC prevalence in his trivariate analysis is curious. Was it because doing so would reveal that HIV risk reduction when MC prevalence is $50 \%-100 \%$ is statistically significant? Even more astonishingly, instead of simply providing the missing ORs, he instead suggested we (or others), "would know that trivariate estimates can be calculated by using the results of table 2 of the original report, which provides the parameters for a simple algebraic equation that can be solved using high-school level math". He then provided a formula $(\operatorname{lnOR}=0.233(x 1)+0.6223(x 2)+0.6269(x 3)-0.2442)$ for others to do the calculations themselves. This curious tactic avoided a direct answer to our criticism that results were missing. Based on the trend in data he did present, the ORs Van Howe did not present were likely to have been statistically significant.

Using Van Howe's formula, we calculated ORs for a general population within Africa with a MC prevalence of $50 \%, 75 \%$ or $100 \%$. For such a population, $x 1=$ $1, x 2=0$, and $x 3=0.50,0.75$ and 1.00 for each respective MC prevalence value. Entering these values into the formula for MC prevalence of $50 \%, 75 \%$ and $100 \%$ yields:

$$
\begin{aligned}
& \operatorname{lnOR}=0.233(1)+0.6223(0)+0.6269(0.50)-0.2442=0.3023 ; \text { thus } \mathrm{OR}=1.35 \\
& \operatorname{lnOR}=0.233(1)+0.6223(0)+0.6269(0.75)-0.2442=0.4590 ; \text { thus } \mathrm{OR}=1.58 \\
& \operatorname{lnOR}=0.233(1)+0.6223(0)+0.6269(1.00)-0.2442=0.6157 ; \text { thus } \mathrm{OR}=1.85
\end{aligned}
$$

Figure 1 shows our results for meta-regression analysis of data on HIV risk 


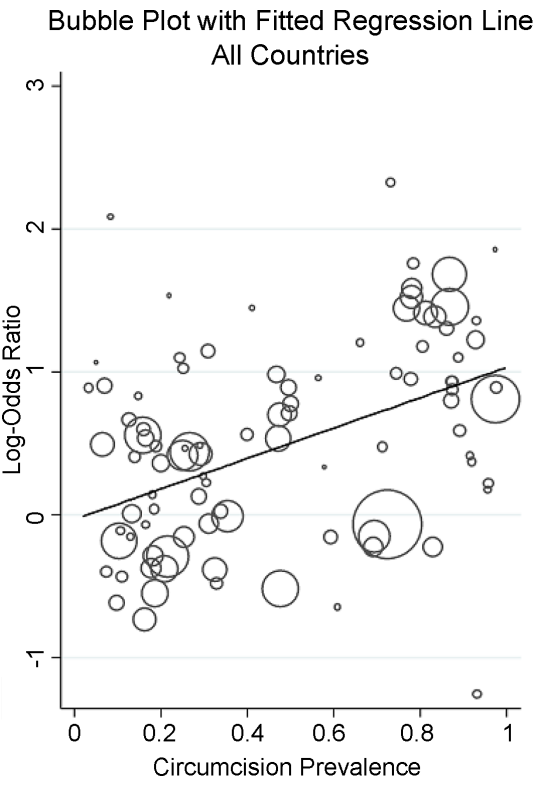

(a)

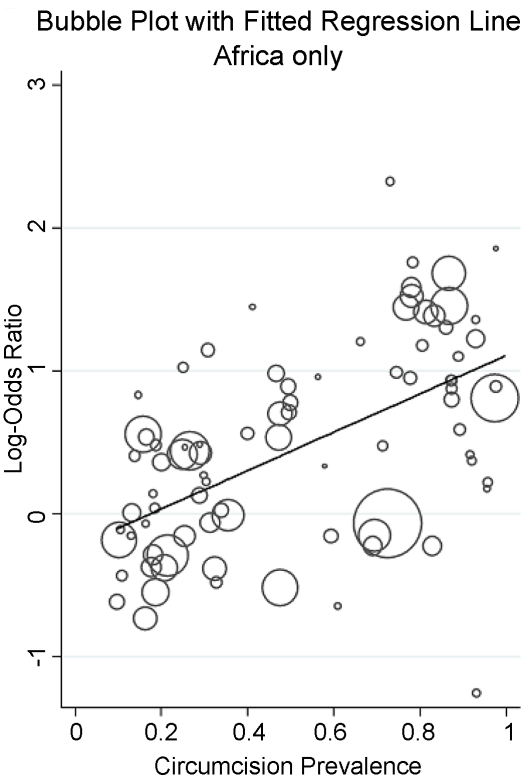

(b)

Figure 1. Meta-regression analysis of log odds of HIV infection between uncircumcised and circumcised men using a single covariate (MC prevalence) in the meta-regression model performed using the metareg package in STATA 13. The plot fits the regression line, with circles representing the estimates from each study, sized according to the precision of each estimate [122]. We have plotted these for all countries (a) and data for Africa only (b), using correct data (see supplementary table in Morris et al. [2] which shows correct values for studies used by Van Howe [3] in his meta-regression analysis). We did not have raw data (or accurate data or data that we could be certain were included in Van Howe's original analysis), which is why we used $n=103$, rather than the $n=109$ studies used by Van Howe.

reduction for MC prevalence of zero through $100 \%$ for all populations worldwide and for African populations only. Circles represent the estimates from each study, sized according to the precision of each estimate [122]. Figure 2 shows prediction interval, confidence interval and log OR using the metareg package [122].

Van Howe also failed to provide an OR in his trivariate model for HIV risk in a general population outside Africa with a MC prevalence of $100 \%$. He omitted to acknowledge that we did in fact perform our own calculation, and we then stated that, "for a general population outside Africa with $100 \% \mathrm{MC}$ our preliminary calculations suggest an OR of 1.5" [2].

Van Howe disagreed with our claim that his conclusion that MC did not protect against HIV resulted from the, "inclusion of questionable MC prevalence estimates in the trivariate model". This is surprising as we did show, in the Supplementary table we provided [2], that he used incorrect data for 14 (29\%) of the 48 studies. While the discrepancy was less than $10 \%$ in 9 of the 14 studies, for 5 studies the discrepancies ranged from $10 \%-78 \%$.

It also seemed to us odd that Van Howe thought that because we did not obtain his dataset and perform the analyses ourselves we do not fit his definition of being "expert". In fact, also not acknowledged by Van Howe, we actually recalculated 


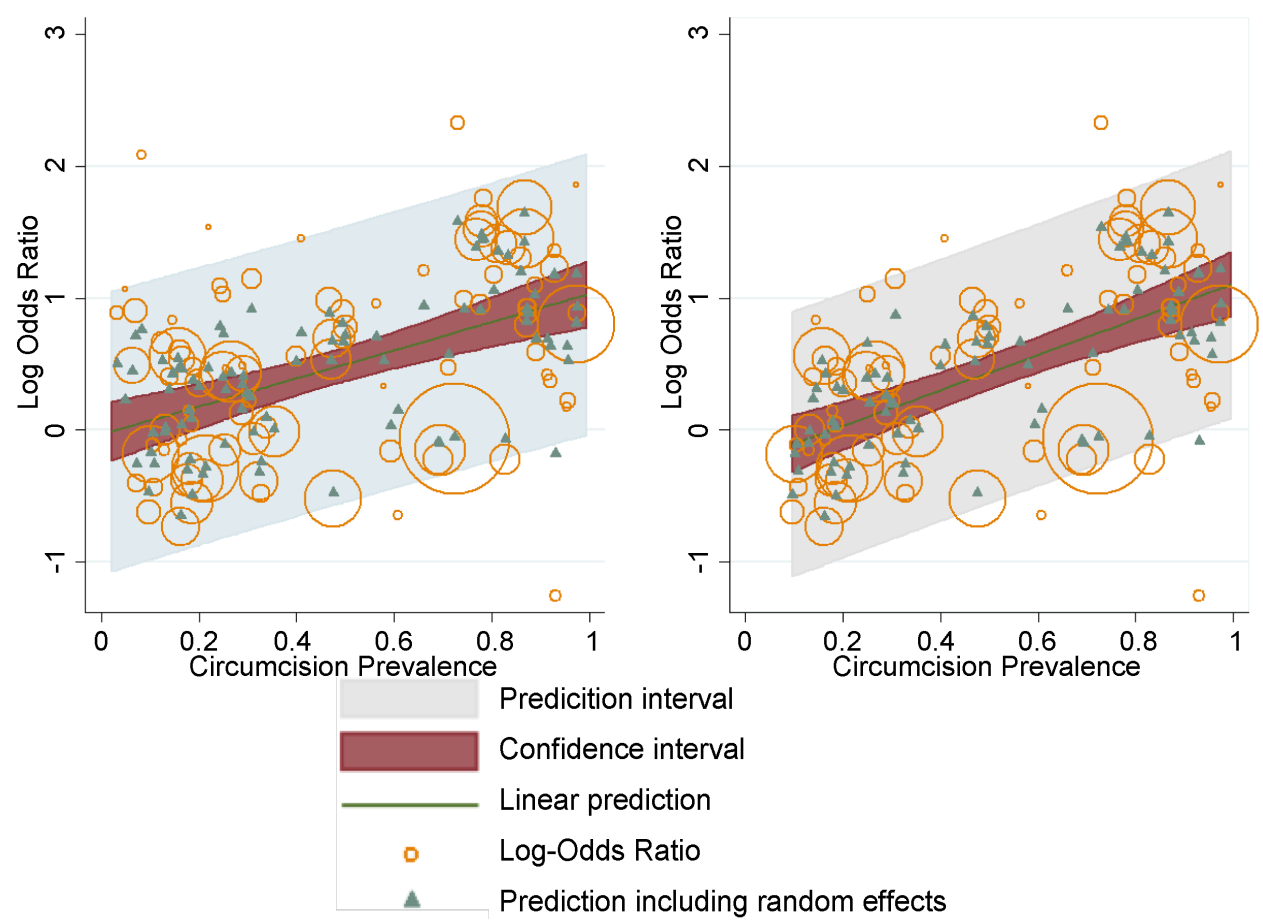

Figure 2. The use of the same meta-regression of the log odds and MC prevalence to show the fitted line and estimates, as well as empirical Bayes estimates resulting from post-estimation. The left panel shows the result for all data. The right panel shows the result for Africa only. The shaded bands show both confidence and prediction intervals, as indicated, in order to visually inspect the fitted model and for model checking. The standard error was used to draw the prediction interval (shown in light gray) around the fitted line, illustrating the uncertainty around the true effect. While we are confident that these estimates would change with the inclusion of additional covariates, the plot gives an indication of the error in this particular case. While we are not confident in our ability to estimate the standard error using aggregate data, our own analyses suggest that considerable variability is unaccounted for in this analysis.

his data using his trivariate model adjusting for location, risk and MC prevalence, confirming his OR of 0.78 for a general population outside Africa with a MC prevalence of $0 \%$. Van Howe did not respond to our ensuing statement that, "this does not, however, seem to be a characteristic of any study included in his analysis" [2].

In summary, in response to Van Howe's concern about, "contributory expertise", we consider that our expertise is sufficient to provide as thorough a critique as might be possible, "as to how [his] analysis was flawed". We did the best we could, given Van Howe's limited description of statistical analyses and variables that appeared in his paper.

\section{Types of Arguments}

\subsection{Was Our Critique Part of a "Broader Inquiry" with Others?}

In item 7 on page 9 of his article, Van Howe did not provide an adequate response to our criticism that his trivariate results included the US for his statement that, "a circumcision programme for the general population (not at high risk) outside 
Africa with circumcision prevalences up to $75 \%$ such as is seen in either Europe, Australia or the USA would not have a significant impact on HIV incidence or prevalence" [1]. We pointed out that in the US, MC prevalence in men exceeds $75 \%$, being $81 \%$ overall ( $91 \%$ in white, $76 \%$ in black and $44 \%$ in Hispanic men) according to the most recent estimates published by CDC researchers [123]. This means that $\mathrm{MC}$ is protective in whites and blacks in the US, even when based on Van Howe's results. Van Howe cited older survey data on US MC rate reported by the CDC [124]. But that study also found overall MC prevalence in the US exceeded $75 \%$, being $79 \%$ overall and $88 \%$ in whites, although prevalence was $73 \%$ in blacks and $42 \%$ in Hispanics. He "cherry-picked" a figure of $56 \%$ from the, "Rates of male circumcision in the United States" section on pages 28 - 29 of the CDC draft MC policy recommendations [125]. The CDC's review presented the $\mathrm{MC}$ rates found in the latter two CDC surveys [123] [124], as well as a rate of 77\% for neonatal MC from National Hospital Discharge Survey figures. The 56\% figure in the CDC review Van Howe cited was for, "circumcision performed during newborn male delivery hospitalizations" only. This figure is only useful for monitoring newborn MC trends, not overall MC rate in the US. Van Howe should have been aware that the 2014 CDC review referred to newborn MC figures by stating, "These surveys document male circumcisions performed in hospitals and billed or coded in discharge diagnoses, but do not ascertain male circumcisions which were not billed or coded, were performed outside hospitals (e.g., circumcision conducted in religious ceremonies), or were performed after the delivery hospitalization". The other MC prevalence figures Van Howe cites are from three older or regional studies that are not nationally representative. The national study in 1997 he cited provided a MC rate of 74\% [126], just shy of the $75 \%$ figure. Our criticism thus stands.

In his item 8 of this section, Van Howe accuses some of us of failing to disclose our association with MC "advocacy groups" [1]. This can only be construed as applying to the first author, Brian Morris, owing to his membership of the Circumcision Academy of Australia, a not-for-profit registered governmentapproved association comprising medical professionals and whose constitution states roles recommended in the American Academy of Pediatric's 2012 infant MC policy [127] [128] of providing accurate unbiased education to parents, provider training and lobbying to improve access, as well as affordability, for infant MC. Lobbying governments and medical bodies seems to be a legitimate means of fulfilling these objectives. Perhaps Van Howe might have disclosed his affiliation with and recognition by "Intact America?".

\subsection{Was Our Critique Aimed at Persuading Others?}

Van Howe accused our critique of attempting to persuade others. To the contrary, it seems he, as other MC opponents, was attempting to persuade others to accept anti-MC reasoning. Van Howe appeared concerned that a conspiracy may be involved in MC promotion for disease prevention. The various programs Van 
Howe lists actually represent the outcome of efforts by various bodies to apply high quality scientific findings to disease prevention programs. Van Howe then expressed concerns about, "imposing the surgery on infant males and young children". Since early infant MC is cheaper, quicker, safer, more convenient and provides immediate and long-term benefits [76], it is logical to introduce voluntary early infant MC programs to ensure those benefits are provided to populations, especially those at high risk. If one were to use Van Howe's logic, vaccination of children would also be delayed until the child reached the age of legal consent. A recent evaluation by professors of law, ethics, medicine, urology and medical sciences found that, given the benefits and low risk, it would be unethical not to recommend early infant MC [53].

\subsection{Was Our Critique Aimed at Defeating Others?}

Van Howe appeared to take criticism of his work and that of other MC opponents personally. We assure Van Howe and other MC opponents that it is the science that we strive to uphold first and foremost. When scientific data are misrepresented and analyses are conducted with the intent to mislead others by promoting a non-evidence-based agenda, any scientist is within their rights to provide counter arguments based on the best available evidence. That was our intent.

\section{Response to Van Howe's Conclusion}

We find little in Van Howe's defense that addresses the concerns raised in our critique [2]. Rather than focusing on the criticisms, we find his arguments to be evasive, using claims and hyperbole in attempting to shore up his purported statistical expertise and knowledge of the MC field. We are not convinced that he uses his expertise impartially. Moreover, Van Howe appears to have tried very hard to deflect criticisms of his work.

Van Howe was correct that the first author, Morris, often with various coauthors, publishes critiques. The intent of these has been to point out scientific errors in publications by MC opponents, not to support MC per se. Van Howe noted that, over time, risk-benefit analysis by Morris [18] [52] [72] [73] [74] [96] have demonstrated a progressive increase in the estimate of proportion of uncircumcised males who will experience an adverse medical condition over their lifetime as a result of having a foreskin, as well as the magnitude of the benefit to risk ratio (as we document in Table 1). Those figures reflect ongoing growth in high quality publications used for successive risk-benefit analyses. The reason no one else has reproduced these figures is because no one else has tried. Van Howe referred to a claim by Frisch and Earp [129] that the relative magnitude of benefits of MC is overstated by a, "factor of approximately 100", but no basis for this claim was provided by those authors. The Canadian Paediatric Society did not perform a risk-benefit analysis, so the quote presented by Van Howe from their position statement is not based on data. It was then left to others to do a risk- 
benefit analysis using incidence figures for various medical conditions in or relevant to Canada [52]. The risk-benefit analysis in that critique found benefits greatly exceeded procedural risks of early infant MC [52]. Interestingly, the summation of risks in the latter was $0.4 \%$ [52], which was identical to the total risk of adverse events for newborn MC found in a large detailed study by CDC researchers [130].

Van Howe cited as support for his claim about MC risk a small Scottish study of 180 boys with UTIs, amongst whom 3 were circumcised to reduce UTI recurrence. We fail to understand how those findings for a single condition are relevant to our risk-benefit analyses of multiple conditions. Van Howe then states that, "the incidence of [UTI] in boys is about 1\%", failing to make clear that this figure applies to uncircumcised boys during infancy. By combining this figure with the Scottish figure for MC to prevent recurrence (rather than for prevention of UTI in the first place) Van Howe went on to misleadingly state, "1 boy in 6000 would be expected to need a circumcision because of [UTI]". For UTI, possession of a foreskin poses a 1 in 4 risk of UTI over the lifetime [77]. In our view the more important issue is prevention, not just of UTI, but of all infections (mostly STIs) and other conditions that uncircumcised males are at elevated risk of over their lifetime. It is therefore not surprising that when risk of all other conditions is added to the risk of infections, one obtains an estimate of over 1 in 2 for the risk to an uncircumcised male of experiencing at least one of those foreskin-attributable conditions over their lifetime [131].

The Danish study by Sneppen and Thorup that Van Howe then referred to stated there was, "significant morbidity related to foreskin problems in a predominantly uncircumcised population" [132]. That study pointed out that the reason most Danish boys might go through infancy, childhood and adolescence without being circumcised reflects, "the strict foreskin-preserving culture of Denmark" [132]. In contrast to Van Howe's misleading statement that this study showed, "only $0.5 \%$ of boys needed circumcision for medical reasons", Sneppen and Thorup noted that, "More than $5 \%$... were admitted to the pediatric surgical department with foreskin-related problems [mainly phimosis] and at least 1.66\% of the boys needed surgical procedures in [sic] general anesthesia" [132]. Of these, $24 \%$ initially and another 5\% after alternative treatment failed, received a circumcision. Moreover, foreskin-preserving preputioplasty had to be repeated in $5.5 \%$ (higher than for MC: $2 \%$ ), further exposing the boy to surgical risks. Thus the, "more than 5\%" of boys that presented initially should have been offered circumcision, since the latter is the definitive treatment, and confers a diversity of other preventive health benefits.

Van Howe then claimed a 1999 study from England found much the same. But that study found, "pathological (cicatrizing)" phimosis (mostly caused by lichen sclerosus) affected $0.6 \%$ of 62 boys aged $5-14$ years by their $15^{\text {th }}$ birthday, "a value lower than previous estimates" [133]. And that, "During the same period 30 boys were circumcised for developmental unretractability of the foreskin 
('physiological phimosis')". Physiological phimosis is much more common than pathological phimosis. Once again, it seems Van Howe failed to convey findings accurately.

Taken together, we do not consider that, "figures quoted by Morris and his co-authors are exaggerated", nor do they represent "hyperbole". Van Howe accuses Morris of a "Gish gallop" of publications on MC. (This term came from the tirade used by Duane Gish, a creationist, to seek to overwhelm objections based on scientific evidence). The term was used against Morris in an online newsletter by the MC opponent Brian Earp [134], which itself was hyperbolic, even using the offensive and quite unprofessional word "bullsh" ${ }^{\star * ”}$ in its title. Van Howe should perhaps appreciate the energy needed by Morris and his co-authors in their struggle to keep up with the "Gish gallop" of articles by MC opponents, by pointing out fundamental errors in those. Since the articles by MC opponents repeat claims repudiated in prior critiques and in high quality systematic reviews and meta-analysis published by Morris and his co-authors as well as by others, it is to be expected that these have been cited in multiple critiques. We appreciate Van Howe's quote of a comment made in 1999 in a book review by Basil Donovan, a Sydney friend of Morris. Donovan's interesting perspective- "Morris is a man on a mission to rid the world of the male foreskin"-more likely reflects Donovan's sense of humor, although seems to us to be somewhat of an exaggeration for effect. Nevertheless, based on the current strong scientific evidence, universal foreskin removal early in infancy should help improve global public health. This is a desirable goal that no responsible person should object to.

\section{Conclusion}

Based on our evaluation of Van Howe's arguments, one should not rely on Van Howe for the "best approximation of the truth" when it comes to scientific evidence in the field of MC. Contrary to the incomplete and questionable meta-regression analysis by Van Howe, our more comprehensive meta-regression analysis shows that MC is able to reduce the risk of HIV in populations worldwide. $\mathrm{MC}$ also reduces the risk of other infections and adverse medical conditions.

\section{References}

[1] Van Howe, R.S. (2017) Expertise or Ideology? A Response to Morris et al. 2016, 'Circumcision Is a Primary Preventive against HIV Infection: Critique of a Contrary Meta-Regression Analysis by Van Howe'. Global Public Health, 2017, 1-19, E-Pub ahead of print Jan 10, 2017. https://doi.org/10.1080/17441692.2016.1272939

[2] Morris, B.J., Barboza, G., Wamai, R.G. and Krieger, J.N. (2017) Circumcision Is a Primary Preventive against HIV Infection: Critique of a Contrary Meta-Regression Analysis by Van Howe. Global Public Health, 2016, 1-11, E-pub ahead of print Apr 4, 2016.

http://dx.doi.org.ezproxy1.library.usyd.edu.au/10.1080/17441692.2016.1272939

[3] Van Howe, R.S. (2015) Circumcision as a Primary HIV Preventive: Extrapolating from the Available Data. Global Public Health, 10, 607-625. http://dx.doi.org/10.1080/17441692.2015.1016446 
[4] Moses, S., Nagelkerke, N.J.D. and Blanchard, J.F. (1999) Commentary: Analysis of the Scientific Literature on Male Circumcision and Risk for HIV Infection. International Journal of STD \& AIDS, 10, 626-628.

[5] O'Farrell, N. and Egger, M. (2000) Circumcision in Men and the Prevention of HIV Infection: A 'Meta-Analysis' Revisited. International Journal of STD \& AIDS, 11, 137-142. https://doi.org/10.1258/0956462001915480

[6] Schoen, E.J. (2005) Circumcision for Preventing Urinary Tract Infections in Boys: North American View. Archives of Disease in Childhood, 90, 772-773. https://doi.org/10.1136/adc.2004.066761

[7] Castellsagué, X., Albero, G., Cleries, R. and Bosch, F.X. (2007) HPV and Circumcision: A Biased, Inaccurate and Misleading Meta-Analysis. Journal of Infection, 55, 91-93. https://doi.org/10.1016/j.jinf.2007.02.009

[8] Schoen, E.J. (2007) Critique of Van Howe RS. Meatal Stenosis Following Neonatal Circumcision. Clinical Paediatrics (Philadelphia), 46, 86. https://doi.org/10.1177/0009922806289836

[9] Waskett, J.H. and Morris, B.J. (2007) Fine-Touch Pressure Thresholds in the Adult Penis. BJU International, 99, 1551-1552. https://doi.org/10.1111/j.1464-410X.2007.06970_6.x

[10] Willcourt, R. (2007) The Effect of Male Circumcision on Sexuality. BJU International, 99, 1169-1170. https://doi.org/10.1111/j.1464-410X.2007.06895_3.x

[11] Waskett, J.H. and Morris, B.J. (2008) Re: 'RS Van Howe, FM Hodges. The Carcinogenicity of Smegma: Debunking a Myth.' An Example of Myth and Mythchief Making? Journal of the European Academy of Dermatology and Venereology, 22, 131. https://doi.org/10.1111/j.1468-3083.2007.02439.x

[12] Waskett, J.H., Morris, B.J. and Weiss, H.A. (2009) Errors in Meta-Analysis by Van Howe. International Journal of STD \& AIDS, 20, 216-218. https://doi.org/10.1258/ijsa.2009.008126

[13] Morris, B.J., Waskett, J.H., Gray, R.H., Halperin, D.T., Wamai, R., Auvert, B. and Klausner, J.D. (2011) Exposé of Misleading Claims That Male Circumcision Will Increase HIV Infections in Africa. Journal of Public Health in Africa, 2, 117-122. https://doi.org/10.4081/jphia.2011.e28

[14] Morris, B.J., Tobian, A.A.R., Hankins, C.A., Klausner, J.D., Banerjee, J., Bailis, S.A., Moses, S. and Wiswell, T.E. (2013) Veracity and Rhetoric in Pediatric Medicine: A Critique of Svoboda and Van Howe's Response to the AAP Policy on Infant Male Circumcision. Journal of Medical Ethics, 40, 463-470. https://doi.org/10.1136/medethics-2013-101614

[15] Morris, B.J., Hankins, C.A., Tobian, A.A., Krieger, J.N. and Klausner, J.D. (2014) Does Male Circumcision Protect against Sexually Transmitted Infections? Arguments and Meta-Analyses to the Contrary Fail to Withstand Scrutiny. ISRN Urology, 2014, Article ID: 684701. http://dx.doi.org/10.1155/2014/684706

[16] Morris, B.J. (2003) Circumcision for Phimosis and Other Medical Indications in Western Australian Boys. [Critical Comment]. Medical Journal of Australia, 178, 588-589.

[17] Morris, B.J. and Bailis, S.A. (2004) Circumcision Rate Too Low? [Critical Comment]. Australian and New Zealand Journal of Surgery, 74, 386-387. https://doi.org/10.1111/j.1445-1433.2004.03008.x

[18] Morris, B.J., Bailis, S.A., Castellsague, X., Wiswell, T.E. and Halperin, D.T. (2006) RACP's Policy Statement on Infant Male Circumcision Is Ill-Conceived. Australian and New Zealand Journal of Public Health, 30, 16-22. 
https://doi.org/10.1111/j.1467-842X.2006.tb00079.x

[19] Morris, B.J. (2007) Circumcision in Australia: Prevalence and Effects on Sexual Health. International Journal of STD \& AIDS, 18, 69-70. https://doi.org/10.1258/095646207779949943

[20] Wamai, R.G., Weiss, H.A., Hankins, C., Agot, K., Karim, Q.A., Shisana, O., Bailey, R.C., Betukumesu, B., Bongaarts, J., Bowa, K., Cash, R., Cates, W., Diallo, M.O., Dludlu, S., Geffen, N., Heywood, M., Jackson, H., Kayembe, P.K., Kapiga, S., Kebaabetswe, P., Kintaudi, L., Klausner, J.D., Leclerc-Madlala, S., Mabuza, K., Makhubele, M.B., Miceni, K., Morris, B.J., de Moya, A., Ncala, J., Ntaganira, I., Nyamucherera, O.F., Otolorin, E.O., Pape, J.W., Phiri, M., Rees, H., Ruiz, M., Sanchez, J., Sawires, S., Seloilwe, E.S., Serwadda, D.M., Setswe, G., Sewankambo, N., Simelane, D., Venter, F., Wilson, D., Woelk, G., Zungu, N. and Halperin, D.T. (2008) Male Circumcision Is an Efficacious, Lasting and Cost-Effective Strategy for Combating HIV in High-Prevalence AIDS Epidemics: Time to Move beyond Debating the Science. Future HIV Therapy, 2, 399-405. https://doi.org/10.2217/17469600.2.5.399

[21] Morris, B.J. and Wodak, A. (2010) Circumcision Survey Misleading. Australian and New Zealand Journal of Public Health, 34, 636-637. https://doi.org/10.1111/j.1753-6405.2010.00642.x

[22] Waskett, J.H. (2010) Fatally Flawed: Bollinger's Circumcision Death Calculations. http://circumcisionnews.blogspot.com.au/2010/05/fatally-flawed-bollingers-circum cision.html

[23] Banerjee, J., Klausner, J.D., Halperin, D.T., Wamai, R., Schoen, E.J., Moses, S., Morris, B.J., Bailis, S.A., Venter, F., Martinson, N., Coates, T.J., Gray, G. and Bowa, K. (2011) Circumcision Denialism Unfounded and Unscientific. [Critique of Green et al., "Male Circumcision and HIV Prevention: Insufficient Evidence and Neglected External Validity"]. American Journal of Preventive Medicine, 40, e11-e12. https://doi.org/10.1016/j.amepre.2010.12.005

[24] Cooper, D.A., Wodak, A.D. and Morris, B.J. (2011) Matters Arising: "The Case for Boosting Infant Male Circumcision in the Face of Rising Heterosexual Transmission of HIV"... And Now the Case against. Author Reply. Medical Journal of Australia, 194, 101.

[25] Wamai, R. and Morris, B.J. (2011) 'How to Contain Generalized HIV Epidemics' Article Misconstrues the Evidence. International Journal of STD \& AIDS, 22, 415416. https://doi.org/10.1258/ijsa.2010.010460

[26] Wamai, R.G., Morris, B.J., Bailis, S.A., Sokal, D., Klausner, J.D., Appleton, R., Sewankambo, N., Cooper, D.A., Bongaarts, J., de Bruyn, G., Wodak, A.D. and Banerjee, J. (2011) Male Circumcision for HIV Prevention: Current Evidence and Implementation in Sub-Saharan Africa. Journal of the International AIDS Society, 14, 117. https://doi.org/10.1186/1758-2652-14-49

[27] Bates, B. and Morris, B.J. (2012) Legal Arguments Opposing Infant Male Circumcision Are Flawed. Internal Medicine Journal, 42, 1281-1282. https://doi.org/10.1111/j.1445-5994.2012.02943.x

[28] Dilley, A.V. and Morris, B.J. (2012) Reply [Correcting Paix's Misunderstandings about Anaesthesia for Neonatal Circumcision.] Internal Medicine Journal, 42, 12771278. https://doi.org/10.1111/j.1445-5994.2012.02945.x

[29] Morris, B.J. (2012) Boyle and Hill's Circumcision 'Phallusies'. BJU International, 110, E153-E154. https://doi.org/10.1111/j.1464-410X.2012.10674_2.x

[30] Morris, B.J., Waskett, J.H. and Gray, R.H. (2012) Does Sexual Function Survey in 
Denmark Offer Any Support for Male Circumcision Having an Adverse Effect? International Journal of Epidemiology, 41, 310-312. https://doi-org.ezproxy1.library.usyd.edu.au/10.1093/ije/dyr180

[31] Morris, B.J. and Waskett, J.H. (2012) Claims that Circumcision Increases Alexithymia and Erectile Dysfunction Are Unfounded. International Journal of Men's Health, 11, 177-181. https://doi.org/10.3149/jmh.1102.177

[32] Morris, B.J., Wodak, A.D., Mindel, A., Schrieber, L., Duggan, K.A., Dilly, A., Willcourt, R.J. and Cooper, D.A. (2012) Reply to Forbes: Evidence-Based Policy: Circumcision of Infant Males. Internal Medicine Journal, 42, 1279-1280. https://doi.org/10.1111/j.1445-5994.2012.02946.x

[33] Morris, B.J., Bailey, R.C., Klausner, J.D., Leibowitz, A., Wamai, R.G., Waskett, J.H., Banerjee, J., Halperin, D.T., Zoloth, L., Weiss, H.A. and Hankins, C.A. (2012) Review: A Critical Evaluation of Arguments Opposing Male Circumcision for HIV Prevention in Developed Countries. AIDS Care, 24, 1565-1575. http://dx.doi.org/10.1080/09540121.2012.661836

[34] Wamai, R.G., Morris, B.J., Waskett, J.H., Green, E.C., Banerjee, J., Bailey, R.C., Klausner, J.D., Sokal, D.C. and Hankins, C.A. (2012) Criticisms of African Trials Fail to Withstand Scrutiny: Male Circumcision Does Prevent HIV Infection. Journal of Law and Medicine, 20, 93-123.

[35] Bates, M.J., Ziegler, J.B., Kennedy, S.E., Mindel, A., Wodak, A.D., Zoloth, L.S., Tobian, A.A.R. and Morris, B.J. (2013) Recommendation by a Law Body to Ban Infant Male Circumcision Has Serious Worldwide Implications for Pediatric Practice and Human Rights. BMC Pediatrics, 13, 1-9. https://doi.org/10.1186/1471-2431-13-136

[36] Klausner, J.D. (2013) Faulty Analysis Leads to Erroneous Conclusions. Journal of Sexual Medicine, 10, 613-614. http://dx.doi.org/10.1111/j.1743-6109.2012.02986.x

[37] Morris, B.J. and Krieger, J.N. (2013) Does Male Circumcision Affect Sexual Function, Sensitivity, or Satisfaction?-A Systematic Review. Journal of Sexual Medicine, 10, 2644-2657. http://dx.doi.org/10.1111/jsm.12293

[38] Morris, B.J. and Tobian, A.A. (2013) Legal Threat to Infant Male Circumcision. JAMA Pediatrics, 167, 890-891. https://doi.org/10.1001/jamapediatrics.2013.2761

[39] Morris, B.J., Krieger, J.N. and Kigozi, G. (2013) Male Circumcision Decreases Penile Sensitivity as Measured in a Large Cohort. BJU International, 111, E269-E270. https://doi.org/10.1111/bju.12128_9

[40] Task Force on Circumcision (2013) Cultural Bias and Circumcision: The AAP Task Force on Circumcision Responds. Pediatrics, 131, 801-804. https://doi.org/10.1542/peds.2013-0081

[41] Morris, B.J. (2014) Scientific Evidence Dispels False Claims about Circumcision. Canadian Urological Association Journal, 8, 396-397. http://dx.doi.org/10.5489/cuaj.2490

[42] Morris, B.J., Bailis, S.A. and Wiswell, T.E. (2014) In Reply-Bias and Male Circumcision. Mayo Clinic Proceedings, 89, 1588-1589. https://doi.org/10.1016/j.mayocp.2014.09.002

[43] Morris, B.J. and Tobian, A.A. (2014) Circumcision Is a Religious/Cultural Procedure, Not a Medical Procedure-Reply. JAMA Pediatrics, 168, 294. https://doi.org/10.1001/jamapediatrics.2013.5110

[44] Morris, B.J. (2015) Commentary: Do the Benefits of Male Circumcision Outweigh the Risks? A Critique of the Proposed CDC Guidelines. [Critique of Earp]. Frontiers in Pediatrics, 3, 88. https://doi.org/10.3389/fped.2015.00088 
[45] Morris, B.J. and Wiswell, T.E. (2015) ‘Circumcision Pain’ Unlikely to Cause Autism. Journal of the Royal Society of Medicine, 108, 297. https://doi.org/10.1177/0141076815590404

[46] Morris, B.J. and Krieger, J.N. (2015) The Literature Supports Policies Promoting Neonatal Male Circumcision in North America. Journal of Sexual Medicine, 12, 1305. https://doi.org/10.1111/jsm.12855

[47] Morris, B.J. and Krieger, J.N. (2015) Male Circumcision Does Not Reduce Sexual Function, Sensitivity or Satisfaction. Advances in Sexual Medicine, 5, 53-60. https://doi.org/10.4236/asm.2015.53007

[48] Wamai, R.G., Morris, B.J., Bailey, R.C., Klausner, J.D. and Boedicker, M.N. (2015) Male Circumcision for Protection against HIV Infection in Sub-Saharan Africa: The Evidence in Favour Justifies the Implementation Now in Progress. Global Public Health, 10, 639-666. https://doi.org/10.1080/17441692.2014.989532

[49] Wamai, R.G., Morris, B.J., Bailey, R.C., Klausner, J.D. and Boedicker, M.N. (2015) Debating Male Circumcision for HIV Prevention: A One-Sided Argument Does Not Represent a Legitimate 'Controversy' Analysis-Reply to de Camargo et al. Global Public Health, 10, 672-678. https://doi.org/10.1080/17441692.2015.1014827

[50] Morris, B.J. and Krieger, J.N. (2016) Letter from Morris and Krieger Re: Examining Penile Sensitivity in Neonatally Circumcised and Intact Men Using Quantitative Sensory Testing: J.A. Bossio, C.F. Pukall and S.S. Steele. J Urol 2016; 195: 1848-1853. Journal of Urology, 196, 1824-1825.

[51] Morris, B.J., Krieger, J.N. and Klausner, J.D. (2016) Critical Evaluation of Unscientific Arguments Disparaging Affirmative Infant Male Circumcision Policy. World Journal of Clinical Pediatrics, 5, 251-261. https://doi.org/10.5409/wjcp.v5.i3.251

[52] Morris, B.J., Klausner, J.D., Krieger, J.N., Willcox, B.J., Crouse, P.D. and Pollock, N. (2016) Canadian Paediatrics Society Position Statement on Newborn Circumcision: A Risk-Benefit Analysis Revisited. Canadian Journal of Urology, 23, 8492-8502.

[53] Rivin, B.E., Diekema, D.E., Mastroianni, A.C., Krieger, J.N., Klausner, J.D. and Morris, B.J. (2016) Critical Evaluation of Adler's Challenge to the CDC's Male Circumcision Recommendations. International Journal of Children's Rights, 24, 265303. https://doi.org/10.1163/15718182-02402004

[54] Wachtel, M.S., Yang, S. and Morris, B.J. (2016) Reply to Letter by Dr. Christoph Kupferschmid: Commentary on "Countries with High Circumcision Prevalence Have Lower Prostate Cancer Mortality”. Asian Journal of Andrology, 18, 950-951. https://doi.org/10.4103/1008-682X.184997

[55] Morris, B.J., Krieger, J.N. and Klausner, J.D. (2017) CDC’s Male Circumcision Recommendations Represent a Key Public Health Measure. Global Health: Science and Practice, 5, 15-27. https://doi.org/10.9745/GHSP-D-16-00390

[56] Morris, B.J., Klausner, J.D., Krieger, J.N., Willcox, B.J., Crouse, P.D. and Pollock, N. (2017) Reply by Authors-Re: Canadian Pediatrics Society Position Statement on Newborn Circumcision: A Risk-Benefit Analysis Revisited. Canadian Journal of Urology, 24, 8687-8692.

[57] Morris, B.J., Krieger, J.N., Klausner, J.D. and Rivin, B.E. (2017) The Ethical Course Is to Recommend Infant Male Circumcision-Arguments Disparaging American Academy of Pediatrics Affirmative Policy Do Not Withstand Scrutiny. Journal of Law Medicine and Ethics, in Press.

[58] Morris, B.J., Wamai, R.G., Krieger, J.N., Banerjee, J. and Klausner, J.D. (2017) Male Circumcision to Prevent Syphilis in 1855 and HIV in 1986 Is Supported by the Accumulated Scientific Evidence to 2015: Response to Darby. Global Public Health, 
2015, 1-19, E-pub ahead of print Nov 13, 2015.

http://dx.doi.org/10.1080/17441692.2015.1104371

[59] Wodak, A.D., Ziegler, J.B. and Morris, B.J. (2017) Infant Circumcision: Evidence, Policy, and Practice. Journal of Paediatrics and Child Health, 53, 93. https://doi.org/10.1111/jpc.13420

[60] Bärnighausen, T., Bloom, D.E. and Humair, S. (2012) Economics of Antiretroviral Treatment vs. Circumcision for HIV Prevention. Proceedings of the National Academy of Sciences USA, 109, 21271-21276. https://doi.org/10.1073/pnas.1209017110

[61] Smith, D.K., Taylor, A., Kilmarx, P.H., Sullivan, P., Warner, L., Kamb, M., Bock, N., Kohmescher, B. and Mastro, T.D. (2010) Male Circumcision in the United States for the Prevention of HIV Infection and Other Adverse Health Outcomes: Report from a CDC Consultation. Public Health Reports, 125, 72-82. https://doi.org/10.1177/00333549101250S110

[62] Van Howe, R.S. (1999) Circumcision and HIV Infection: Review of the Literature and Meta-Analysis. International Journal of STD \& AIDS, 10, 8-16. https://doi.org/10.1258/0956462991913015

[63] Dickersin, K. and Berlin, J.A. (1992) Meta-Analysis: State-of-the-Science. Epidemiologic Reviews, 14, 154-176. https://doi.org/10.1093/oxfordjournals.epirev.a036084

[64] Rothman, K.J. (1986) Modern Epidemiology. Little Brown and Company, Boston.

[65] Barker, F.G. and Carter, B.S. (2005) Synthesizing Medical Evidence: Systematic Reviews and Meta-Analyses. Neurosurgical Focus, 19, E5. https://doi.org/10.3171/foc.2005.19.4.6

[66] Borenstein, M., Hedges, L., Higgins, J.P.T. and Rothstein, H.R. (2009) Introduction to Meta-Analysis. John Wiley and Sons, West Sussex. https://doi.org/10.1002/9780470743386

[67] Van Howe, R.S. (2007) Human Papillomavirus and Circumcision: A Meta-Analysis. Journal of Infection, 54, 490-496. https://doi.org/10.1016/j.jinf.2006.08.005

[68] Sorrells, M.L., Snyder, J.L., Reiss, M.D., Eden, C., Milos, M.F., Wilcox, N. and Van Howe, R.S. (2007) Fine-Touch Pressure Thresholds in the Adult Penis. BJU International, 99, 864-869. https://doi.org/10.1111/j.1464-410X.2006.06685.x

[69] Young, H. (2007) Fine-Touch Pressure Thresholds in the Adult Penis. [Letter to the Editor]. BJU International, 100, 699. https://doi.org/10.1111/j.1464-410X.2007.07072_1.x

[70] Bossio, J.A., Pukall, C.F. and Steele, S.S. (2016) Examining Penile Sensitivity in Neonatally Circumcised and Intact Men Using Quantitative Sensory Testing. Journal of Urology, 195, 1848-1853. https://doi.org/10.1016/j.juro.2015.12.080

[71] Peters, J. and Mengersen, K. (2008) Selective Reporting of Adjusted Estimates in Observational Epidemiology Studies: Reasons and Implications for Meta-Analyses. Evaluation \& the Health Professions, 31, 370-389. https://doi.org/10.1177/0163278708324438

[72] Morris, B.J. (2007) Why Circumcision Is a Biomedical Imperative for the 21st Century. BioEssays, 29, 1147-1158. https://doi.org/10.1002/bies.20654

[73] Morris, B.J., Wodak, A.D., Mindel, A., Schrieber, L., Duggan, K.A., Dilly, A., Willcourt, R.J., Cooper, D.A., Lumbers, E.R., Russell, C.T. and Leeder, S.R. (2012) Infant Male Circumcision: An Evidence-Based Policy Statement. Open Journal of Preventive Medicine, 2, 79-92. https://doi.org/10.4236/ojpm.2012.21012

[74] Morris, B.J., Kennedy, S.E., Wodak, A.D., Mindel, A., Golovsky, D., Schrieber, L., 
Lumbers, E.R., Handelsman, D.J. and Ziegler, J.B. (2017) Early Infant Male Circumcision: Systematic Review, Risk-Benefit Analysis, and Progress in Policy. World Journal of Clinical Pediatrics, 6, 89-102. https://doi.org/10.5409/wjcp.v6.i1.89

[75] Morris, B.J., Gray, R.H., Castellsague, X., Bosch, F.X., Halperin, D.T., Waskett, J.H. and Hankins, C.A. (2011) The Strong Protection Afforded by Circumcision Against Cancer of the Penis. (Invited Review). Advances in Urology, 2011, Article ID: 812368. http://dx.doi.org/10.1155/2011/812368

[76] Morris, B.J., Waskett, J.H., Banerjee, J., Wamai, R.G., Tobian, A.A.R., Gray, R.H., Bailis, S.A., Bailey, R.C., Klausner, J.D., Willcourt, R.J., Halperin, D.T., Wiswell, T.E. and Mindel, A. (2012) A 'Snip' in Time: What Is the Best Age to Circumcise? BMC Pediatrics, 12, 1-15. https://doi.org/10.1186/1471-2431-12-20

[77] Morris, B.J. and Wiswell, T.E. (2013) Circumcision and Lifetime Risk of Urinary Tract Infection: A Systematic Review and Meta-Analysis. Journal of Urology, 189, 2118-2124. https://doi.org/10.1016/j.juro.2012.11.114

[78] Morris, B.J. and Krieger, J.N. (2017) Penile Inflammatory Skin Disorders and the Preventive Role of Circumcision. International Journal of Preventive Medicine, 8 , 32. http://www.ijpvmjournal.net/text.asp?2017/8/1/32/205695 https://doi.org/10.4103/ijpvm.IJPVM_377_16

[79] Morris, B.J., Wamai, R.G., Henebeng, E.B., Tobian, A.A.R., Klausner, J.D., Banerjee, J. and Hankins, C.A. (2016) Estimation of Country-Specific and Global Prevalence of Male Circumcision. Population Health Metrics, 14, 11. https://doi.org/10.1186/s12963-016-0073-5

[80] Morris, B.J., Wamai, R.G., Henebeng, E.B., Tobian, A.A., Klausner, J.D., Banerjee, J. and Hankins, C.A. (2016) Erratum to: Estimation of Country-Specific and Global Prevalence of Male Circumcision. Population Health Metrics, 14, 11. https://doi.org/10.1186/s12963-016-0080-6

[81] New York Times (1995) Hollywood Madam's Father Pleads Guilty. http://www.nytimes.com/1995/05/12/us/hollywood-madam-s-father-pleads-guilty.h $\underline{\mathrm{tml}}$

[82] Hubler, S. (1995) Paul Fleiss Gets Probation for Aiding Heidi: Court: Crowd of Supporters Turns out as Pediatrician Avoids Prison Time for Helping Daughter Hide Profits from Call-Girl Ring. http://articles.latimes.com/1995-09-19/local/me-47682_1_heidi-fleiss

[83] London, W.M. (2014) Medical Renegade Paul M. Fleiss, M.D. Dead at 80. http://www.skepticink.com/health/2014/08/12/medical-renegade-paul-m-fleiss-m-d -dead-80/

[84] Svoboda, J.S., Adler, P.W. and Van Howe, R.S. (2016) Circumcision Is Unethical and Unlawful. Journal of Law, Medicine and Ethics, 44, 263-282.

[85] Bollinger, D. and Van Howe, R.S. (2011) Alexithymia and Circumcision Trauma: A Preliminary Investigation. International Journal of Men's Health, 10, 184-195. https://doi.org/10.3149/jmh.1002.184

[86] Darby, R. and Van Howe, R.S. (2011) Not a Surgical Vaccine: There Is No Case for Boosting Infant Male Circumcision to Combat Heterosexual Transmission of HIV in Australia. Australian and New Zealand Journal of Public Health, 35, 459-465. https://doi.org/10.1111/j.1753-6405.2011.00761.x

[87] Fleiss, P.M., Hodges, F.M. and Van Howe, R.S. (1998) Immunological Functions of the Human Prepuce. Sexually Transmitted Infections, 74, 364-367. https://doi.org/10.1136/sti.74.5.364

[88] Van Howe, R.S. and Hodges, F.M. (2006) The Carcinogenicity of Smegma: De- 
bunking a Myth. Journal of the European Academy of Dermatology and Venereology, 20, 1046-1054. https://doi.org/10.1111/j.1468-3083.2006.01653.x

[89] Van Howe, R.S., Svoboda, J.S. and Hodges, F.M. (2005) HIV Infection and Circumcision: Cutting through the Hyperbole. Journal of the Royal Society for the Promotion of Health, 125, 259-265. https://doi.org/10.1177/146642400512500607

[90] Hodges, F.M., Svoboda, J.S. and Van Howe, R.S. (2002) Prophylactic Interventions on Children: Balancing Human Rights with Public Health. Journal of Medical Ethics, 28, 10-16. https://doi.org/10.1136/jme.28.1.10

[91] Van Howe, R.S., Sorrells, M.S., Snyder, J.L., Reiss, M.D. and Milos, M.F. (2016) Letter from Van Howe et al Re: Examining Penile Sensitivity in Neonatally Circumcised and Intact Men Using Quantitative Sensory Testing: J. A. Bossio, C. F. Pukall and S. S. Steele J Urol 2016; 195: 1848-1853. Journal of Urology, 196, 1824.

[92] Van Howe, R.S. and Svoboda, J.S. (2008) Neonatal Circumcision Is Neither Medically Necessary Nor Ethically Permissible: A Response to Clark et al. Comment to: Mandatory Neonatal Circumcision in Sub-Saharan Africa: Medical and Ethical Analysis. Peter Clark, Justin Eisenman, Stephen Szapor Med Sci Monit 2007; 13(12): RA205-13. [Letter to the Editor]. Medical Science Monitor, 14, LE7-LE13.

[93] Svoboda, J.S., Van Howe, R.S. and Dwyer, J.G. (2000) Informed Consent for Neonatal Circumcision: An Ethical and Legal Conundrum. Journal of Contemporary Health Law Policy, 17, 61-133.

[94] Van Howe, R.S., Svoboda, J.S., Dwyer, J.G. and Price, C.P. (1999) Involuntary Circumcision: The Legal Issues. BJU International, 83, 63-73. https://doi.org/10.1046/j.1464-410x.1999.0830s1063.x

[95] Kalichman, S.C. (2009) Denying AIDS: Conspiracy Theories, Pseudoscience, and Human Tragedy. Copernicus Books, New York. https://doi.org/10.1007/978-0-387-79476-1

[96] Morris, B.J., Bailis, S.A. and Wiswell, T.E. (2014) Circumcision Rates in the United States: Rising or Falling? What Effect Might the New Affirmative Pediatric Policy Statement Have? Mayo Clinic Proceedings, 89, 677-686. https://doi.org/10.1016/j.mayocp.2014.01.001

[97] Tian, Y., Liu, W., Wang, J.Z., Wazir, R., Yue, X. and Wang, K.J. (2013) Effects of Circumcision on Male Sexual Functions: A Systematic Review and Meta-Analysis. Asian Journal of Andrology, 15, 662-666. https://doi.org/10.1038/aja.2013.47

[98] Morris, B.J. and Krieger, J.N. (2017) Penile Inflammatory Skin Disorders and the Preventive Role of Circumcision. International Journal of Preventive Medicine, 8 , 32. https://doi.org/10.4103/ijpvm.IJPVM_377_16

[99] Morris, B.J. and Krieger, J.N. (2017) Does Circumcision Increase Meatal Stenosis Risk?-A Systematic Review and Meta-Analysis. Urology, in press.

[100] Morris, B.J. and Nightingale, B.N. (1987) A Method of Detection of Carcinogenic Papillomavirus. US Patents No. 5783412 and 6218104; European Patent No. 88902077.2-2107 (British, 0357611; German, P 3853678.1; Swiss, 3853678.1; Swedish, 0357611), Japanese Patent 3096704; Australian Patent No. 611135.

[101] Yang, Y., Wang, X., Bai, Y. and Han, P. (2017) Circumcision Does Not Have Effect on Premature Ejaculation: A Systematic Review and Meta-Analysis. Andrologia, E-pub ahead of print June 27, 2017. https://doi.org/10.1111/and.12851

[102] Shabanzadeh, D.M., During, S. and Frimont-Moller, C. (2016) Male Circumcision Does Not Result in Inferior Perceived Male Sexual Function-A Systematic Review. Danish Medical Journal, 63, Article ID: A5245. 
[103] Homfray, V., Tanton, C., Mitchell, K.R., Miller, R.F., Field, N., Macdowall, W., Wellings, K., Sonnenberg, P., Johnson, A.M. and Mercer, C.H. (2015) Examining the Association between Male Circumcision and Sexual Function: Evidence from a British Probability Survey. AIDS, 29, 1411-1416. https://doi.org/10.1097/QAD.0000000000000745

[104] Wiswell, T.E., Smith, F.R. and Bass, J.W. (1985) Decreased Incidence of Urinary Tract Infections in Circumcised Male Infants. Pediatrics, 75, 901-903. https://doi.org/10.1016/S0022-5347(17)47483-0

[105] Wiswell, T.E. and Hachey, W.E. (1993) Urinary Tract Infections and the Circumcision State: An Update. Clinical Pediatrics, 32, 130-134. https://doi.org/10.1177/000992289303200301

[106] Singh-Grewal, D., Macdessi, J. and Craig, J. (2005) Circumcision for the Prevention of Urinary Tract Infections in Boys: A Systematic Review of Randomized Trials and Observational Studies. Archives of Disease in Childhood, 90, 853-858. https://doi.org/10.1136/adc.2004.049353

[107] Whitstock, M. (2015) Reducing Adverse Events in Older Patients Taking Newly Released Drugs. Verlay/Scholar's Press, Saarbruken.

[108] Auvert, B., Taljaard, D., Lagarde, E., Sobngwi-Tambekou, J., Sitta, R. and Puren, A. (2005) Randomized, Controlled Intervention Trial of Male Circumcision for Reduction of HIV Infection Risk: The ANRS 1265 Trial. PLoS Medicine, 2, 1112-1122. https://doi.org/10.1371/journal.pmed.0020298

[109] Bailey, R.C., Moses, S., Parker, C.B., Agot, K., Maclean, I., Krieger, J.N., Williams, C.F., Campbell, R.T. and Ndinya-Achola, J.O. (2007) Male Circumcision for HIV Prevention in Young Men in Kisumu, Kenya: A Randomised Controlled Trial. Lancet, 369, 643-656. https://doi.org/10.1016/S0140-6736(07)60312-2

[110] Gray, R.H., Kigozi, G., Serwadda, D., Makumbi, F., Watya, S., Nalugoda, F., Kiwanuka, N., Moulton, L.H., Chaudhary, M.A., Chen, M.Z., Sewankambo, N.K., Wabwire-Mangen, F., Bacon, M.C., Williams, C.F., Opendi, P., Reynolds, S.J., Laeyendecker, O., Quinn, T.C. and Wawer, M.J. (2007) Male Circumcision for HIV Prevention in Men in Rakai, Uganda: A Randomised Trial. Lancet, 369, 657-666. https://doi.org/10.1016/S0140-6736(07)60313-4

[111] Siegfried, N., Muller, M., Deeks, J.J. and Volmink, J. (2009) Male Circumcision for Prevention of Heterosexual Acquisition of HIV in Men. Cochrane Database Systematic Reviews, 2, Article ID: CD003362. https://doi.org/10.1002/14651858.CD003362.pub2

[112] Weiss, H.A., Halperin, D., Bailey, R.C., Hayes, R.J., Schmid, G. and Hankins, C.A. (2008) Male Circumcision for HIV Prevention: From Evidence to Action? (Review). AIDS, 22, 567-574. https://doi.org/10.1097/QAD.0b013e3282f3f406

[113] Weiss, H.A., Quigley, M.A. and Hayes, R.J. (2000) Male Circumcision and Risk of HIV Infection in Sub-Saharan Africa: A Systematic Review and Meta-Analysis. AIDS, 14, 2361-2370. https://doi.org/10.1097/00002030-200010200-00018

[114] Lei, J.H., Liu, L.R., Wei, Q., Yan, S.B., Yang, L., Song, T.R., Yuan, H.C., Lv, X. and Han, P. (2015) Circumcision Status and Risk of HIV Acquisition during Heterosexual Intercourse for Both Males and Females: A Meta-Analysis. PLoS One, 10, e0125436. https://doi.org/10.1371/journal.pone.0125436

[115] Morton, S.C., Adams, J.L. and Suttorp, M.J. (2004) Meta-Regression Approaches: What, Why, When, and How? (Technical Reviews, No. 8.) 1, Introduction. Agency for Healthcare Research and Quality, Rockville.

http://www.ncbi.nlm.nih.gov/books/NBK43897/ 
[116] Van Howe, R.S. (2009) Reply to Letter from Mr Waskett, Professor Morris and Dr Weiss. International Journal of STD \& AIDS, 20, 592. https://doi.org/10.1258/ijsa.2009.08r126

[117] Conroy, E.J., Harman, N.L., Lane, J.A., Lewis, S.C., Murray, G., Norrie, J., Sydes, M.R. and Gamble, C. (2015) Trial Steering Committees in Randomised Controlled Trials: A Survey of Registered Clinical Trials Units to Establish Current Practice and Experiences. Clinical Trials, 12, 664-676. https://doi.org/10.1177/1740774515589959

[118] Boyle, G.J. and Hill, G. (2011) Sub-Saharan African Randomized Clinical Trials into Male Circumcision and HIV Transmission: Methodological, Ethical and Legal Concerns. Journal of Law and Medicine, 19, 316-333.

[119] Gray, R., Kigozi, G., Kong, X., Ssempiija, V., Makumbi, F., Wattya, S., Serwadda, D., Nalugoda, F., Sewenkambo, N.K. and Wawer, M.J. (2012) The Effectiveness of Male Circumcision for HIV Prevention and Effects on Risk Behaviors in a Post-Trial Follow up Study in Rakai, Uganda. AIDS, 26, 609-615. https://doi.org/10.1097/QAD.0b013e3283504a3f

[120] Mehta, S.D., Moses, S., Agot, K., Maclean, I., Odoyo-June, E., Li, H. and Bailey, R.C. (2013) Medical Male Circumcision and HSV-2 Acquisition: Post-Trial Surveillance in Kisumu, Kenya. Journal of Infectious Diseases, 208, 1869-1876. https://doi.org/10.1093/infdis/jit371

[121] Auvert, B., Taljaard, D., Rech, D., Lissouba, P., Singh, B., Bouscaillou, J., Peytavin, G., Mahiane, S.G., Sitta, R., Puren, A. and Lewis, D. (2013) Association of the ANRS-12126 Male Circumcision Project with HIV Levels among Men in a South African Township: Evaluation of Effectiveness Using Cross-Sectional Surveys. PLoS Medicine, 10, 1-12. https://doi.org/10.1371/journal.pmed.1001509

[122] Harbord, R.M. and Higgins, J.P. (2008) Meta-Regression in Stata. Stata Journal, 8, 493-519.

[123] Introcaso, C.E., Xu, F., Kilmarx, P.H., Zaidi, A. and Markowitz, L.E. (2013) Prevalence of Circumcision among Men and Boys Aged 14 to 59 Years in the United States, National Health and Nutrition Examination Surveys 2005-2010. Sexually Transmitted Diseases, 40, 521-525. https://doi.org/10.1097/01.OLQ.0000430797.56499.0d

[124] Xu, F., Markowitz, L.E., Sternberg, M.R. and Aral, S.O. (2007) Prevalence of Circumcision and Herpes Simplex Virus Type 2 Infection in Men in the United States: The National Health and Nutrition Examination Survey (NHANES), 1999-2004. Sexually Transmitted Diseases, 34, 479-484.

[125] Centers for Disease Control and Prevention (2014) [Docket No. CDC-2014-00120002] Recommendations for Providers Counselling Male Patients and Parents Regarding Male Circumcision and the Prevention of HIV Infection, STIs, and Other Health Outcomes.

https://www.regulations.gov/document?D=CDC-2014-0012-0002

[126] Laumann, E.O., Paik, A. and Rosen, R.C. (1999) Sexual Dysfunction in the United States: Prevalence and Predictors. JAMA, 281, 537-544. https://doi.org/10.1001/jama.281.6.537

[127] American Academy of Pediatrics Task Force on Circumcision (2012) Male Circumcision. Pediatrics, 130, e756-e785. https://doi.org/10.1542/peds.2012-1990

[128] American Academy of Pediatrics Task Force on Circumcision (2012) Circumcision Policy Statement. Pediatrics, 130, 585-586. https://doi.org/10.1542/peds.2012-1989

[129] Frisch, M. and Earp, B.D. (2016) Circumcision of Male Infants and Children as a Public Health Measure in Developed Countries: A Critical Assessment of Recent 
Evidence. Global Public Health, 19, 1-16, E-pub ahead of print May 19, 2016. https://doi.org/10.1080/17441692.2016.1184292

[130] El Bcheraoui, C., Zhang, X., Cooper, C.S., Rose, C.E., Kilmarx, P.H. and Chen, R.T. (2014) Rates of Adverse Events Associated with Male Circumcision in US Medical Settings, 2001 to 2010. JAMA Pediatrics, 168, 625-634.

https://doi.org/10.1001/jamapediatrics.2013.5414

[131] Morris, B.J., Kennedy, S.E., Wodak, A.D., Mindel, A., Golovsky, D., Schrieber, L., Lumbers, E.R., Handelsman, D.J. and Ziegler, J.B. (2017) Early Infant Male Circumcision: Systematic Review, Risk-Benefit Analysis, and Progress in Policy. World Journal of Clinical Pediatrics, 6, 89-102. https://doi.org/10.5409/wjcp.v6.i1.89

[132] Sneppen, I. and Thorup, J. (2016) Foreskin Morbidity in Uncircumcised Males. Pediatrics, 137, e20154340. https://doi.org/10.1542/peds.2015-4340

[133] Shankar, K.R. and Rickwood, A.M. (1999) The Incidence of Phimosis in Boys. BJU International, 84, 101-102. https://doi.org/10.1046/j.1464-410x.1999.00147.x

[134] Earp, B.D. (2016) The Unbearable Assymetry of Bullshit. HealthWatch Newsletter, $101,4-5$

\section{Scientific Research Publishing}

\section{Submit or recommend next manuscript to SCIRP and we will provide best} service for you:

Accepting pre-submission inquiries through Email, Facebook, LinkedIn, Twitter, etc. A wide selection of journals (inclusive of 9 subjects, more than 200 journals) Providing 24-hour high-quality service

User-friendly online submission system Fair and swift peer-review system Efficient typesetting and proofreading procedure Display of the result of downloads and visits, as well as the number of cited articles Maximum dissemination of your research work

Submit your manuscript at: http://papersubmission.scirp.org/ Or contact wja@scirp.org 